\title{
Pengaruh beberapa teknik pengendalian terhadap keragaman dan intensitas berbagai jenis penyakit yang muncul pada pertanaman pepaya di Pekon Way Nipah Kecamatan Pematang Sawa
}

\author{
Effect of control techniques against the diversity and intensity of several plant \\ diseases on Papaya in Pekon Way Nipah Region of Pematang Sawa \\ Firnando $^{1}$, Radix Suharjo²,* Joko Prasetyo ${ }^{2}$, Muhammad Nurdin², \\ I Gede Swibawa ${ }^{2}$, Franciscus Xaverius Susilo ${ }^{2}$
}

${ }^{1}$ Department of Agroteknologi, Faculty of Agriculture, Universitas Lampung, Lampung, Indonesia.

${ }^{2}$ Department of Proteksi Tanaman, Faculty of Agriculture, Universitas Lampung, Lampung, Indonesia

\section{INFORMASI ARTIKEL \\ *Korespondensi: Radix Suharjo radix.suharjo@fp.unila.ac.id}

Informasi proses: Received: 1 Juni 2020 Accepted: 8 Juni 2020 Published: 14 Juli 2020

Cara sitasi: Firnando, Suharjo R, Prastyo J, Nurdin M, Swibawa IG, Susilo FX. 2020. Pengaruh beberapa teknik pengendalian terhadap keragaman dan intensitas berbagai jenis penyakityang muncul pada pertanaman pepaya di Pekon Way Nipah Kecamatan Pematang Sawa. Jurnal Proteksi Tanaman Tropis 1(2): 33-43

DOI:

\begin{abstract}
The study was aimed to determine the diseases in papaya plantations and to evaluate the effect of various disease control techniques against the intensity of disease in papaya plants in Pekon Way Nipah, Pematang Sawa District, Lampung. This research was conducted in October 2018 to May 2019 in the Biotechnology Laboratory, Faculty of Agriculture, University of Lampung and in Pekon Way Nipah, Pematang Sawa, Tanggamus, Lampung. This study was randomized block designed (RBD) with eight treatments consisting of control (K), biological spray agent (AHSP), manure plus biological agents $(\mathrm{PK}+\mathrm{AH})$, soil biological treatment agent (AHSI), bactericide spray (BSP)), manure (PK), solarization (SL), and tillage (OT). The study showed that the diseases that occurred on papaya plantations were suspected as powdery mildew, brown spots 1 , brown spots 2 , curly cladosporium, leaf curly, root rot and stem base. The treatment of manure plus biological agents reduced the severity of brown spot 1 , brown spot 2, powdery mildew, and cladospsorium curling while solarization treatment suppressed the occurrence of root rot and base stem disease.
\end{abstract}

Key words: Disease severity, disease incidence, papaya plantations, diagnosis.

\section{Pendahuluan}

Pepaya merupakan tanaman yang memiliki khasiat dan manfaat di setiap bagian tanamannya. Mulai dari akar, daun, buah, biji, bahkan getahnya dapat dimanfaatkan oleh manusia. Akar tanaman pepaya dapat digunakan sebagai obat cacing, mencegah resiko batu ginjal, hipertensi dan rematik. Daun tanaman pepaya dapat digunakan sebagai pengontrol tekanan darah, obat demam berdarah, obat nyeri perut saat haid, anemia dan masuk angin. Buah pepaya banyak mengandung vitamin seperti vitamin A, B1 dan C, selain itu buah pepaya juga mengandung serat dan mineral. Biji pepaya dapat digunakan sebagai obat cacingan. Getahnya dapat digunakan sebagai obat luka bakar, gatal-gatal dikulit dan pelunak daging (Muktiani, 2011).

Semakin meningkatnya kesadaran masyarakat akan pentingnya buah pepaya, menyebabkan permintaan terhadap pepaya terus mengalami peningkatan, sehingga jumlah dan pasokan pepaya harus ditingkatkan. Menurut BPS (2018), produksi 
pepaya di provinsi Lampung dalam rentang waktu 2014-2017 mengalami fluktuasi pada tahun 2014 adalah 104.131 ton, tahun 2015 mengalami penurunan produksi dengan total produksi 70.542 ton, Tahun 2016 mengalami peningkatan dengan total produksi 88.107 ton, dan pada tahun 2017 mengalami penurun kembali dengan total produksi 80.364 ton. Namun begitu, usaha peningkatan produksi pepaya menjadi kurang optimal karena adanya permasalahan penyakit tanaman. Menurut Semangun (2007), beberapa penyakit yang ditemukan pada tanaman pepaya yaitu penyakit busuk akar dan pangkal batang, bercak daun Corynespora, papaya ringspot virus (PRSV), mosaik pepaya, busuk buah antraknosa, busuk buah Rhizopus dan penyakit mati pucuk yang disebabkan oleh Erwinia papayae.

Berbagai upaya telah dilakukan untuk meminimalisir kerugian akibat serangan patogen tanaman tersebut. Selain menggunakan pestisida, perkembangan patogen dapat ditekan dengan menggunakan teknik pengendalian yang ramah lingkungan. Berikut ini beberapa teknik yang dapat digunakan seperti pemanfaatan agensia hayati, penggunaaan pupuk kandang, solarisasi, olah tanah dan kombinasinya.

Penelitian ini bertujuan untuk mengetahui jenisjenis penyakit yang muncul pada pertanaman pepaya serta pengaruh berbagai teknik pengendalian penyakit terhadap intesitas penyakit pada tanaman pepaya di Pekon Way Nipah Kec. Pematang Sawa Kab. Tanggamus.

\section{Metode penelitian}

\section{Waktu dan Rancangan percobaan}

Penelitian ini dilaksanakan di dua tempat, yaitu di Pekon Way Nipah, Kecamatan Pematang Sawa, Kabupaten Tanggamus, Lampung untuk penanaman pepaya dan pengamatan intensitas penyakit dan di Laboratorium Bioteknologi Pertanian Fakultas Pertanian Universitas Lampung untuk penyiapan isolat agensia hayati dan identifikasi patogen yang menyerang tanaman pepaya. Penelitian ini dilaksanakan dari bulan Oktober 2018 hingga Mei 2019. Penelitian ini disusun dengan menggunakan Rancangan Acak Kelompok dengan perlakuan yaitu K= Kontrol negatif (tanpa Perlakuan); AHSp= Agensia hayati spray; $\mathrm{PK}+\mathrm{AH}=$ Pupuk kandang ditambah agensia hayati; AHSI= Agensia hayati, soil treatment; Bsp= Kontrol Positif (Bakterisida dengan bahan aktif (Enrofloxacin) konsentrasi 0,5 ml/l; PK= Pupuk Kandang; SL= Solarisasi; OT= Olah tanah. Seluruh perlakuan diulang sebanyak 3 kali sehingga jumlah satuan percobaan ada 24 petak dengan luas perpetak $1,5 \times 5 \mathrm{~m}^{2}$ (Gambar 1).

Penyiapan Bibit Pepaya. Persiapan diawali dengan mensterilkan tanah dan pasir. Tanah dan pasir yang digunakan untuk pembibitan dengan perbandingan $3: 1$. Selanjutnya media tanam dikukus selama 3 jam. Kegiatan ini menggunakan drum yang dipanaskan. Setelah itu, campuran tanah dan pasir dimasukan kedalam polibag, kemudian benih pepaya ditanam. Bibit pepaya siap di pindah tanam berumur 6 minggu setelah tanam. Bibit yang sehat dipindah tanam kelahan penelitian yang sudah disediakan.

Penyiapan Lahan. Lahan yang akan digunakan untuk penelitian diukur terlebih dahulu. Total luas lahan yang digunakan adalah $437 \mathrm{~m}^{2}$. Setelah itu lahan dibersihkan dari gulma- gulma yang tumbuh di lahan. Selanjutnya dibuat petak percobaan dengan ukuran 5 $\mathrm{m} \times 1,5 \mathrm{~m}$ dengan jarak antar baris, yaitu 2 meter dan jarak antar petak adalah 1 meter. Setelah itu dibuat lubang tanam kecuali pada perlakuan olah tanah dengan ukuran $40 \times 40 \times 40 \mathrm{~cm}$ dengan jarak antar lubang adalah 1 meter pada setiap petaknya.

Penanaman.Bibit pepaya yang telah berumur 6 minggu sudah siap untuk dipindah tanam. Penanaman pepaya sebaiknya dilakukan pada sore hari. Sebelum bibit ditanam polibag dilepas terlebih dahulu. Diambil 1 buah bibit, genggam dan padatkan tanah pada polibag setelah polibag dilepas atau dirobek. Selanjutnya bibit ditanam di lubang yang telah disiapkan kemudian lubang tanam ditutup kembali dengan tanah.

Pemeliharaan. Pemeliharaan rutin yang dilakukan meliputi penyiangan gulma, dan pemupukan. Penyiangan gulma dilakukan dengan mencabuti gulma yang tumbuh dipetak percobaan. Waktu aplikasi yaitu 30 hari setelah tanam sebanyak $20 \mathrm{~g} /$ tanaman dan 60 hari setelah tanam $50 \mathrm{~g} /$ tanaman.

\section{Pelaksanaan Percobaan}

Solarisasi. Pada perlakuan solarisasi terdapat beberapa tahap sebagai berikut. Plot yang telah dibuat lubang tanam selanjutnya ditutup dengan plastik bening dan pinggirannya ditutup rapat mengunakan tanah, perlakuan solarisasi ini dilakukan selama 30 hari. Setelah 30 hari plastik dibongkar selanjutnya bibit pepaya ditanam.

Olah Tanah. Pada perlakuan olah tanah setelah dilakukan ploting, selanjutnya gulma dibersihkan dan tanah digemburkan. Setelah itu, tanah dibuat guludan dengan ketinggian kurang lebih $15 \mathrm{~cm}$. Selanjutnya dibuat lubang tanam.

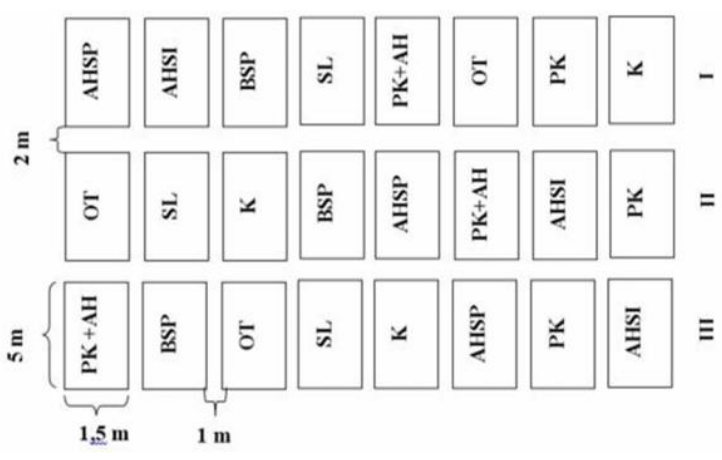

Gambar 1. Tata letak petak percobaan 
Apikasi Pupuk Kandang. Pada perlakuan ini menggunakan pupuk kandang sapi. Pupuk kandang yang diaplikasikan sebanyak $5 \mathrm{~kg}$ per lubang tanam. Aplikasi ini dilakukan setelah dibuat lubang tanam. Setelah itu, didiamkan selama \pm 30 hari supaya pupuk kandang tersebut terdekomposisi secara sempurna.

Aplikasi Agensia Hayati. Pengaplikasian agensia hayati dimulai dari penyiapan agensia hayati, pembuatan media PDA, inokulai agensia hayati pada media PDA, dan perbanyakan agensia hayati pada media beras. Setelah didapatkan biakan agensia hayati pada media beras baru dilakukan aplikasi di lapangan.

Penyiapan Agensia Hayati. Sepuluh jamur agensia hayati yang akan digunakan merupakan koleksi dari Laboratorium Bioteknologi Pertanian, Fakultas Pertanian, Universitas Lampung. Sepuluh jamur yang akan digunakan yaitu Aspergillus sp. (A1, A6, A7, A9) dan 6 isolat Talaromyces sp. (A2, A3, A4, A5, A8 dan A11).

Pembuatan Media Potato Dextrose Agar (PDA). Media PDA dibuat dengan pencampuran ekstrak kentang, dekstrosa dan agar. Satu liter media PDA membutuhkan $200 \mathrm{~g}$ kentang, $20 \mathrm{~g}$ dekstrosa, dan $20 \mathrm{~g}$ agar. Sebanyak $200 \mathrm{~g}$ kentang dipotong kecil sampai ukurannya $\pm 1 \mathrm{~mm}$ dan kemudian direbus dalam 1 liter akuades menggunakan microwave. Ekstrak hasil perebusan kemudian dimasukkan ke dalam erlenmeyer $1000 \mathrm{ml}$ yang telah berisi dekstros dan agar, lalu ditambahkan akuades sampai volumenya $1000 \mathrm{ml}$. Tabung erlenmeyer kemudian ditutup dengan aluminium foil dan diikat menggunakan karet gelang. Selanjutnya, erlenmeyer berisi bahan media dimasukkan ke dalam plastik tahan panas dan diautoklaf selama 15 menit dalam suhu $121^{\circ} \mathrm{C}$ dengan tekanan $1 \mathrm{~atm}$. Setelah di autoklaf, media PDA ditambahkan larutan asam laktat sebanyak $1,4 \mathrm{ml}$ untuk mencegah media terkontaminasi oleh bakteri.

Inokulasi Agensia Hayati pada Media PDA. Masing-masing jamur antagonis berumur 7 hari diinokulasi dengan cara mengambil satu bor gabus biakan jamur berukuran $5 \mathrm{~mm}$ lalu diletakkan ditengah media PDA di dalam cawan petri. Inokulasi jamur tersebut dilakukan di dalam Laminar Air Flow agar hasil inokulasi tidak kontaminan dengan mikroorganisme lain. Setelah jamur berumur 7 hari, kemudian diperbanyak dengan menggunakan media beras.

Perbanyakan Agensia Hayati pada Media Beras. Biakan jamur yang telah didapatkan kemudian diperbanyak pada media beras. Beras dicuci bersih kemudian dikukus diatas air yang mendidih selama 15 menit. Selanjutnya beras kukus dimasukkan ke dalam plastik tahan panas. Kemudian disterilkan dalam autolkaf pada suhu $121^{\circ} \mathrm{C}$ dengan tekanan $1 \mathrm{~atm}$ selama 15 menit. Tiga bor gabus Aspergillus sp., atau Talaromyces sp. yang berumur 7 hari dimasukkan dalam masing-masing media dan diberi label. Kemudian seluruh media diinkubasi.
Aplikasi Agensia Hayati. Sebelum jamur Aspergillus sp. dan Talaromyces sp. diaplikasikan terlebih dahulu dicampurkan satu dengan yang lainnya. Masing-masing biakan jamur Aspergillus sp. dan Talaromyces sp. yang didapatkan kemudian dicampurkan dengan perbandingan satu berbanding satu. Kemudian biakan jamur dihomogenkan sampai tercampur satu dengan yang lainnya. Setelah itu, ditimbang 100 gram untuk pengaplikasian di lapangan. Agensia hayati yang telah dicampurkan dan ditimbang. Selanjutnya diaplikasikan dengan cara ditabur di lubang tanam (PK +AH dan AHSI) dan disemprotkan ke tanaman (AHSp). Pengaplikasian secara ditabur di lubang tanam dilakukkan berbarengan dengan penanaman tanaman papaya dan untuk perlakuan pupuk kandang ditambah agensia hayati $(\mathrm{PK}+\mathrm{AH})$ terlebih dahulu diaduk dengan pupuk kandang yang telah diaplikasikkan terlebih dahulu. Pada perlakuan $\mathrm{PK}+\mathrm{AH}$ dan AHSI agensia hayati diaplikasikan hanya sekali yaitu berbarengan dengan penanaman bibit pepaya. Sedangkan untuk perlakuan agensia hayati spray (AHSP) aplikasi dilakukan seminggu sekali.

Cara aplikasi jamur Aspergillus sp. dan Talaromyces sp. dengan disemprotkan ke tanaman terdapat beberapa tahap. Pertama 100 gram biakan jamur Aspergillus sp. dan Talaromyces sp. ditambah air sebanyak 15 liter. Setelah itu, ditambah 0,25 kg gula pasir yang sudah diencerkan kedalam suspensi jamur dan diaduk. Kemudian dimasukan ke dalam sprayer atau alat semprot dan dilakukan kalibrasi. Pengaplikasi ini dilakukan satu minggu sekali.

\section{Parameter Pengamatan}

Jenis penyakit yang muncul. Tipe penyakit tanaman dapat dibedakan menjadi dua tipe, yaitu: Gejala lokal dan gejala sistemik. Gejala lokal terdapat di suatu tempat atau bagian tanaman tertentu, misalnya pada buah, bunga, cabang, batang, atau akar tanaman. Gejala sistemik, tipe penyakit ini menyebar ke seluruh bagian tanaman, misalnya penyakit yang disebabkan oleh virus (Ginting, 2013). Keterjadian Penyakit. Keterjadian penyakit diamati setiap minggu selama 16 kali pengamatan. Berdasarkan sifat penyakit yang sistemik maka keterjadian penyakit dihitung dengan rumus:

$$
\% P t=\frac{n}{N} \times 100
$$

Dimana $\mathrm{Pt}=\%$ keterjadian penyakit; $\mathrm{n}=$ jumlah tanaman terinfeksi; $\mathrm{N}=$ Jumlah total tanaman yang diamati.

Keparahan Penyakit. Pengamatan keparahan penyakit dilakukan pada bagian daun tanaman yang bergejala. Pengamatan ini menggunakan sistem skor (Gambar 2). Kategori skor kerusakan pada bagian daun tersebut berdasarkan skor kerusakan yaitu skor $0=$ Tidak terdapat gejala; $1=$ Gejala timbul $1-10 \%$; $2=$ Gejala terjadi pada $11-25 \%$; $3=$ Gejala terjadi pada 26 $-50 \%$; $4=$ Gejala terjadi $>50 \%$ (Ginting, 2013) 

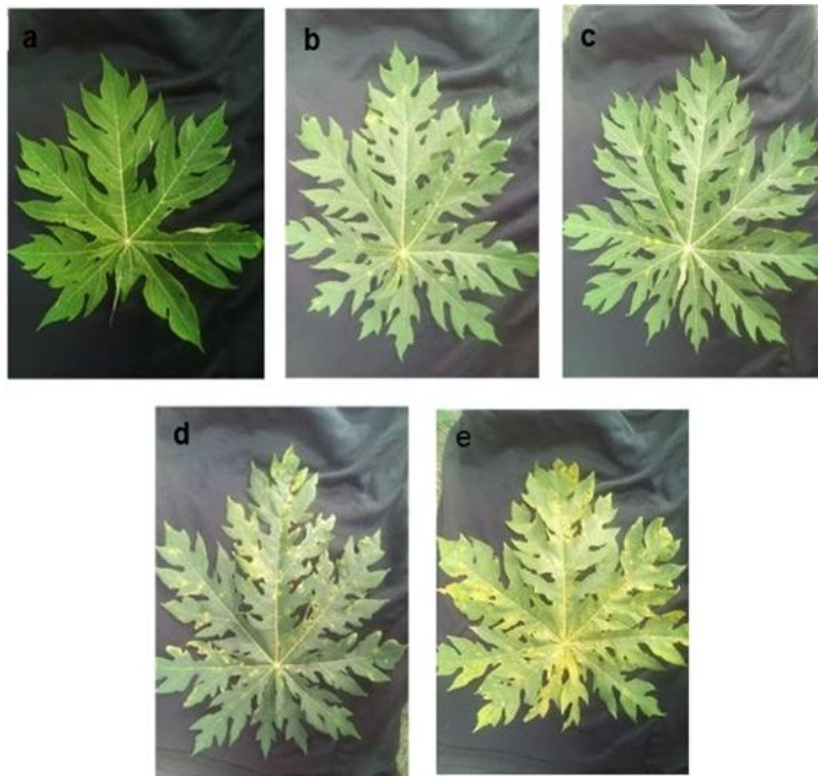

Gambar 2. Kriteria skor yang digunakan a) Skor 0, b) Skor 1, c) Skor 2, d) Skor 3, dan e) Skor 4 Setelah skor semua sampel diketahui.

Pengamatan keparahan penyakit dilakukan satu minggu sekali selama 16 minggu. Keparahan penyakit dihitung dengan menggunakan persamaan:

$$
\mathrm{Kp}(\%)=\frac{\sum(n i \times v i)}{N \times Z} \times 100
$$

Dimana $\mathrm{Kp}=$ keparahan penyakit (\%); ni: Jumlah daun yang sakit dengan nilai skor $\mathrm{i}$; vi= nilai numerik (skor) daun-i; N= Jumlah daun yang diamati; Z= Skor yang lebih tinggi.

Tinggi Tanaman. Tinggi tanaman diukur setiap dua minggu sekali setelah pindah tanam hingga tanaman berumur 16 minggu setelah pindah tanam. Pengukuran tinggi tanaman dilakukan dengan cara mengukur mulai dari pangkal batang sampai titik tumbuh tanaman.

Identifikasi Patogen. Identifikasi dilakukan berdasarkan kenampakan gejala baik makrokopis maupun mikrokopis. Identifikasi makrokopis dengan menyamakan gejala yang tampak dengan bantuan buku Semangun (2007). Selain itu dilakukan pengamatan mikrokopis untuk menentukan patogen dengan bantuan buku Watanabe (2002).

Analisis Data. Homogenitas data di uji dengan uji Bartlet dan additivitas data diuji menggunakan uji Tukey. Jika hasil uji tersebut memenuhi asumsi, maka data dianalisis dengan sidik ragam (ANARA). Selanjutnya dilakukan pengujian nilai tengah dengan uji Bada Nyata Terkecil (BNT) pada taraf $5 \%$.

\section{Hasil Penelitian}

\section{Jenis Gejala yang Muncul}

Hasil pengamatan menunjukkan bahwa pada setiap tanaman memiliki lebih dari satu gejala penyakit. Gejala - gejala yang muncul selama pengamatan berlangsung antara lain; embun tepung, bercak coklat
1, bercak coklat 2 , keriting, busuk akar dan pangkal batang, dan keriting cladosporium.

\section{Embun Tepung}

Gejala pertama yang muncul pada tanaman pepaya adalah pada daun pepaya terdapat bercak-bercak, dan di kedua permukaan daun terdapat seperti tepung, tetapi lebih dominan pada bagian bawah daun. Pada permukaan atas daun terlihat adanya bercak-bercak kuning sampai hijau muda. Bercak yang ditimbulkan agak kebasah - basahan. Gejala ini muncul pada 1 MST sampai dengan 3 MST (Tabel 1), Dengan gejala penyakit tersebut diduga merupakan penyakit embun tepung (Gambar 3).

\section{Bercak Coklat 1}

Gejala selajutnya terlihat pada 3 MST (Tabel 1). Gejala tersebut ditandai dengan bercak pada daun yang berwarna coklat (Gambar 4a). Gejala lanjutan bercak tersebut berwarna coklat agak gelap. Gejala ini paling banyak ditemukan pada daun tua. Hasil isolasi didapatkan isolat jamur berwarna ke abu - abuan dengan pertumbuhan isolat melingkar dan dipinggirnya terdapat miselium bewarna putih (Gambar 4c). Pengamatan mikroskopis dari jamur patogen yang berhasil diisolasi tidak ditemukan struktur khusus jamur patogen tersebut (Gambar 4). Oleh karena itu pendugaan jenis penyakit melalui gejala yang muncul. Berdasarkan gejala yang muncul penyakit tersebut diduga merupakan penyakit antraknosa.
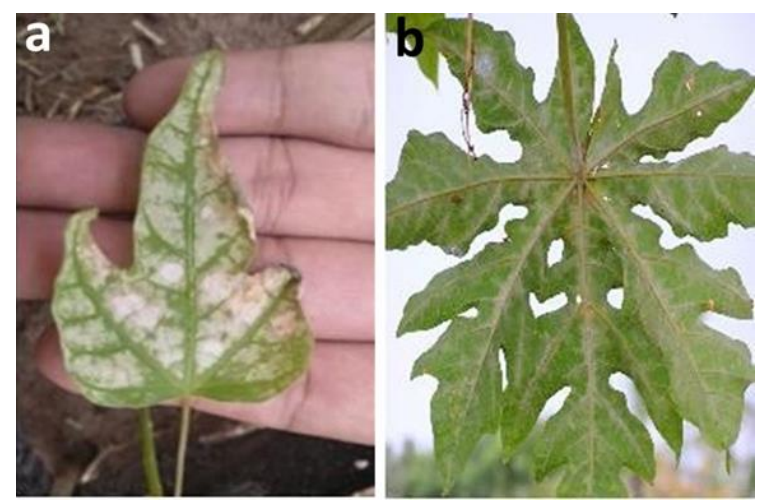

Gambar 3. a) gejala embun tepung di lapangan, b) gejala embun tepung (Cunningham and Nelson, 2012).

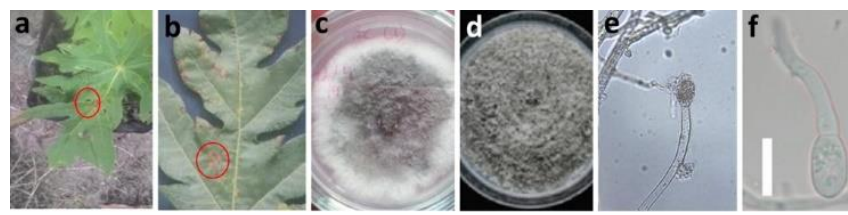

Gambar 4. a) gejala antraknosa di lapangan, b) gejala antraknosa (Wiyono dan Manuwoto, 2008), c) hasil isolasi, d) isolat Colletrotichum sp. (Rangkuti dkk, 2017), e) konidia, f) konidia (Wike dkk, 2011). 
Tabel 1. Kemunculan gejala penyakit pada tanaman pepaya pada berbagai perlakuan

\begin{tabular}{|c|c|c|c|c|c|c|c|c|}
\hline \multirow[t]{2}{*}{ UT } & \multicolumn{8}{|c|}{ Perlakuan } \\
\hline & $\mathrm{K}$ & $\mathrm{PK}+\mathrm{AH}$ & AHSI & AHSP & BSP & PK & SL & $\mathrm{OT}$ \\
\hline 1 & I & I & I & I & I & I & I & I \\
\hline 2 & I, II & I & I, II & I, II & I, II & I, II & I, II & I, II \\
\hline 3 & I, III & I, III & I, III & I, III & I, III & I, II, III & I, III & I, II, III \\
\hline 4 & III & II, III & II, III & II, III & II, III & III & III & III \\
\hline 5 & III & II, III & III & III & II,III & III & III & II, III \\
\hline 6 & III & III & II, III & III & III & III & III & II, III \\
\hline 7 & IV & IV & IV & II, IV & IV & IV & IV & IV \\
\hline 8 & II, IV, V & IV,V & $\mathrm{IV}, \mathrm{V}$ & IV, V & IV, V & IV,V & IV, V & IV, V \\
\hline 9 & IV, V & IV, V, VI & $\mathrm{IV}, \mathrm{V}$ & II, IV, V & IV, V & II, IV,V, VI & IV, V, VI & IV, V \\
\hline 10 & II, IV, V & IV, V, VI & $\mathrm{IV}, \mathrm{V}$ & $\mathrm{IV}, \mathrm{V}$ & IV,V & $\mathrm{IV}, \mathrm{V}, \mathrm{VI}$ & IV,V,VI & IV, V \\
\hline 11 & II, IV, V & V, IV, VI & IV, V & IV, V & II, IV, V & V, IV, VI & V, IV, VI & IV, V \\
\hline 12 & IV & IV, VI & IV & II, IV & II, IV & IV, VI & IV, VI & II, IV \\
\hline 13 & IV & II, IV, VI & II, IV & IV & IV & IV,VI & IV, VI & IV, VI \\
\hline 14 & II, IV & IV, VI & IV & IV & II, IV & IV,VI & IV, VI & IV, VI \\
\hline 15 & II, IV & II, IV, VI & IV & IV & IV & II, IV, VI & IV, VI & IV, VI \\
\hline 16 & IV & IV, VI & IV & IV & IV & IV, VI & IV, VI & IV, VI \\
\hline$\Sigma$ & 5 & 6 & 5 & 5 & 5 & 6 & 6 & 6 \\
\hline
\end{tabular}

Keterangan: UT = Umur Tanaman (MST) I = gejala embun tepung, II = gejala penyakit busuk akar dan pangkal batang, III = gejala penyakit bercak coklat $1, \mathrm{IV}=$ gejala penyakit bercak coklat $2, \mathrm{~V}=$ daun keriting, $\mathrm{VI}=$ gejala keriting cladosporium

\section{Bercak Coklat 2}

Gejala yang keempat muncul saat tanaman berumur 7 MST (Tabel 1). Gejala ini terjadi pada daun yang ditandai dengan bercak berbentuk bulat. Pada bagian tengah gejala berwarna coklat muda dan bagian luar berwarna coklat kekuningan (Gambar 5a). hasil isolasi jamur berwarna ke abu - abuan (Gambar 5c).

Pengamatan mikroskopis dari jamur patogen yang berhasil diisolasi tidak ditemukan struktur khusus jamur patogen tersebut, hanya ditemukan struktur hifa bersekat (Gambar 5e). Oleh karena itu pendugaan jenis penyakit melalui gejala yang muncul. Berdasarkan ciriciri gejala yang muncul, diduga penyakit tersebut disebabkan oleh Corynespora sp. (Gambar 5b).

\section{Busuk akar dan pangkal batang}

Gejala lain yang muncul mula-mula tanaman layu, menguning dan daun-daun bawah menggantung sebelum rontok. Selanjutnya daun-daun yang lebih muda menunjukkan gejala yang sama, sehingga tanaman hanya menyisahkan sedikit daun pada sekitar titik tumbuh tanaman (Gambar 6a) dan akhirnya tanaman mati. Apabila tanaman yang mati digali akan tampak gejala pada akar yang membusuk berwarna coklat dan lunak (6b). Gejala seperti ini ditemukan pada tanaman pepaya berumur 2 MST sampai 15 MST (Tabel 1). Jamur yang didapatkan mirip dengan koloni jamur Phytophthora sp.

Namun begitu, pengamatan mikroskopis dari jamur patogen yang berhasil diisolasi tidak ditemukan struktur khusus jamur patogen tersebut, hanya ditemuka struktur hifa yang tidak bersekat (Gambar 6e) Oleh karena itu pendugaan jenis penyakit melalui gejala yang muncul. Berdasarkan gejalayang muncul diduga gejala tersebut merupakan gejala dari penyakit busuk akar dan pangkal batang (Gambar 6c) yang disebabkan oleh Phytophthora sp.
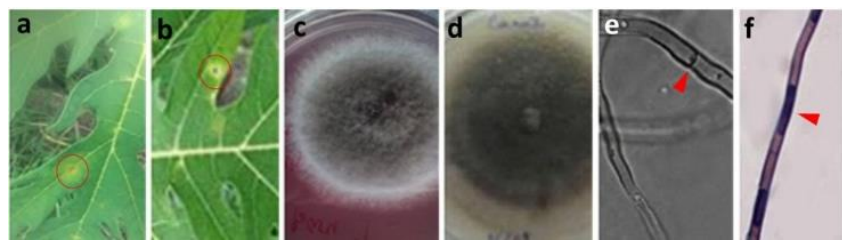

Gambar 5. a) gejala di lapangan, b) gejala bercak corynespora (Silva dkk., 2018), hasil isolasi, d) isolat Corynespora sp. (Silva dkk., 2018), e) hifa hasil identifikasi, f) hifa (Kumar dan Singh, 2016).
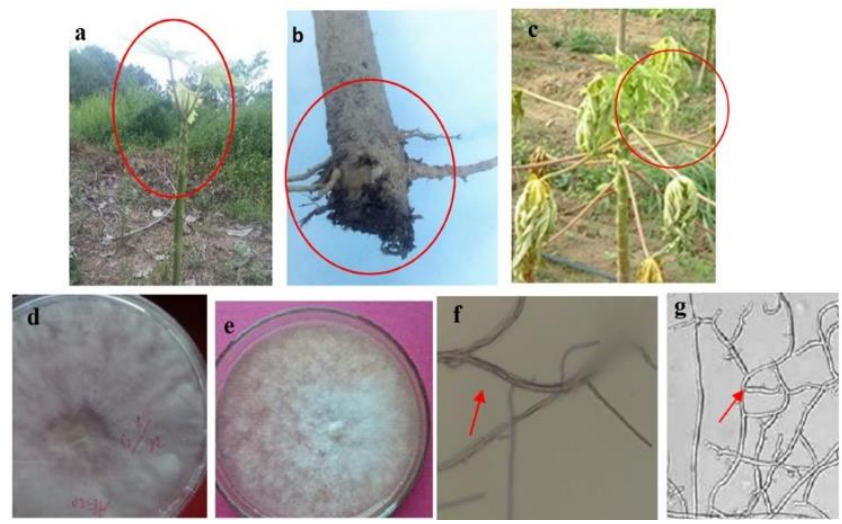

Gambar 6. a) gejala yang ditemukan di lapangan, b) akar tanaman busuk, gejala busuk akar dan pangkal batang (Sulistio, 2018), hasil isolasi, e) Isolat Phytophthora sp. (Singh dkk, 2017), f) hifa tak bersekat, g) hifa Phytophthora sp. (Gaulin dkk, 2002).

\section{Keriting Cladosporium}

Gejala yang terakhir yaitu pada daun muda mengkriting dan terlihat bintik-bintik klorosis. Gejala lebih lanjut beberapa bintik - bintik tersebut berubah menjadi gejala seperti tertembus peluru. Gejala yang lebih parah daun menjadi sobek-sobek (Gambar 7a). Dari gejala tersebut diduga peyakit ini adalah penyakit keriting cladosporium (Gambar 7b). Hasil isolasi didapatkan isolat jamur yang memiliki ciri-ciri isolat 
berwarna hijau tua dan terdapat warna putih tipis di atasnya. pertumbuhan isolat melingkar. Hasil uji patogenitas menunjukkan hal yang positif. Hasil identifikasi mikrokopis konidium berbentuk menyerupai buah lemon, konidium dibentuk berantai pada ujung konidiofor (Gambar 7).

\section{Keriting}

Gejala selanjutnya adalah mengkritingnya daun. Gejala ini terdeteksi pada tanaman berumur 8 MST (Tabel 1). Pada tanaman yang bergejala daun menggulung kebawah. Gejala selanjutnya adalah jarak antar tangkai daun menjadi lebih rapat dan pertumbuhan tanaman terganggu (Gambar 8a). Diduga penyakit ini adalah penyakit keriting pada daun pepaya (Gambar 8b).

Dari pengamatan gejala penyakit pada tanaman pepaya memiiki waktu kemunculan yang berbeda-beda antara gejala yang satu dengan yang lainnya hal ini dapat dilihat pada Tabel 2. Penyakit embun tepung mulai muncul pada minggu pertama dan menghilang pada minggu ke-4. Gejala penyakit bercak coklat 1 mulai muncul pada 3 MST sampai dengan 6 MST. Gejala penyakit bercak coklat 2 mulai muncul saat tanaman berumur 7 MST dan masih dapat ditemukan ketika tanaman berumur 16 MST. Gejala busuk akar dan pangkal batang muncul pada 2 MST sampai dengan 15 MST. Gejala daun keriting dimulai pada 8 MST sampai dengan 12 MST. Dan gejala yang terakhir adalah keriting cladosporium yang mulai muncul pada 9 MST sampai dengan 16 MST. Menghilangnya gejala penyakit embun tepung, bercak coklat 1, dan keriting daun salah satunya karena daun yang bergejala rontok dan tergantikan oleh daun muda yang sehat.

\section{Keparahan Penyakit}

Pengamatan keparahan penyakit dilakukan pada daun yang bergejala. Pengamatan ini menggunakan sistem skoring. Penghitungan keparahan penyakit digunakan untuk gejala penyakit lokal. Berikut ini gejala penyakit lokal yang didapatkan; embun tepung, bercak daun 1 , bercak daun 2, keriting cladosporium dan keriting.

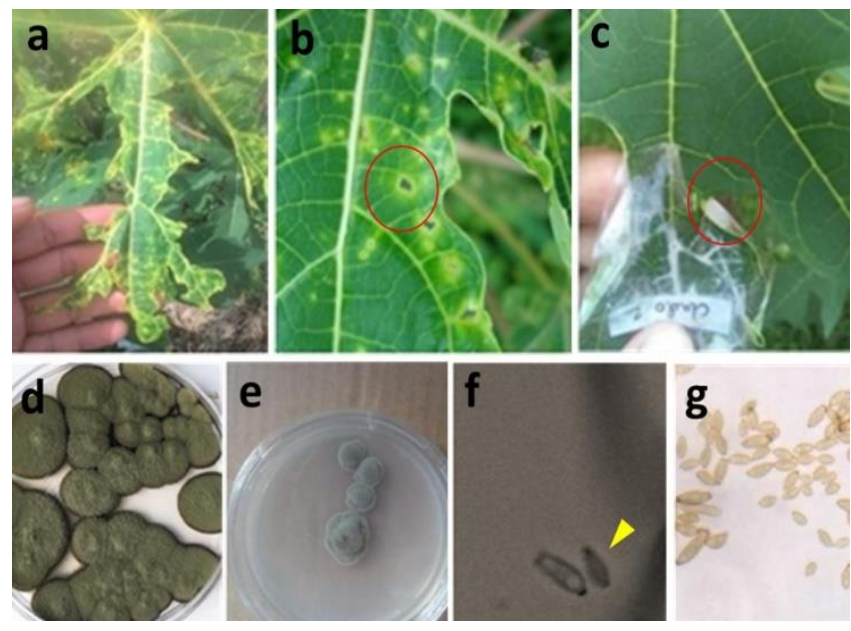

Gambar 7. a) gejala yang ditemukan di lapang, b) gejala keriting cladosporium (Widodo dan Wiyono, 2012), c) hasil uji patogenitas, Isolat Cladosporium sp (Torres dkk. 2017) e) Isolat Cladosporium hasil isolasi, f) konidium (400 x), g) konidium (Torres dkk., 2017).
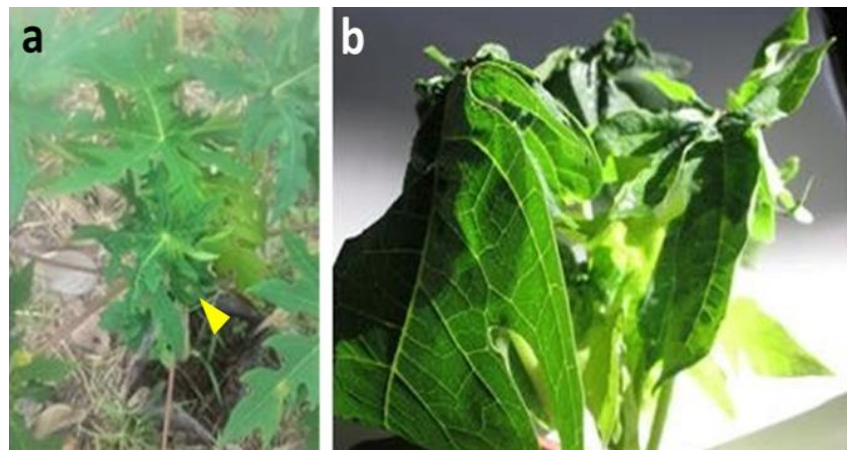

Gambar 8. a) Gejala yang ditemukan di lapang, b) gejala penyakit kriting daun pepaya (Ministry of Agriculture of India, 2014).

Tabel 2. Waktu kemunculan gejala

\begin{tabular}{|c|c|c|c|c|c|c|}
\hline $\begin{array}{l}\text { Umur tanaman } \\
\text { (MST) }\end{array}$ & $\begin{array}{l}\text { Embun } \\
\text { tepung }\end{array}$ & $\begin{array}{l}\text { Bercak, } \\
\text { coklat } 1\end{array}$ & $\begin{array}{c}\text { Bercak } \\
\text { coklat } 2 \\
\end{array}$ & $\begin{array}{c}\text { Busuk Akar \& } \\
\text { Pangkal Batang }\end{array}$ & Keriting & $\begin{array}{c}\text { Bercak } \\
\text { Cladosporium }\end{array}$ \\
\hline 1 & + & - & - & - & - & - \\
\hline 2 & + & - & - & + & - & - \\
\hline 3 & + & + & - & + & - & - \\
\hline 4 & - & + & - & + & - & - \\
\hline 5 & - & + & - & + & - & - \\
\hline 6 & - & + & - & + & - & - \\
\hline 7 & - & - & + & + & - & - \\
\hline 8 & - & - & + & + & + & - \\
\hline 9 & - & - & + & + & + & + \\
\hline 10 & - & - & + & + & + & + \\
\hline 11 & - & - & + & + & + & + \\
\hline 12 & - & - & + & + & - & + \\
\hline 13 & - & - & + & + & - & + \\
\hline 14 & - & - & + & + & - & + \\
\hline 15 & - & - & + & + & - & + \\
\hline 16 & - & - & + & - & - & + \\
\hline
\end{tabular}

Keterangan: + = bergejala, - = tidak bergejala 


\section{Keparahan Penyakit Embun Tepung}

Hasil analis ragam keparahan penyakit embun tepung pada 1 MST memperlihatkan bahwa perlakuan berpengaruh nyata dan pada 2 MST dan 3 MST tidak berpengaruh nyata. Pada 1 MST (Tabel 3) perlakuan kontrol berbeda nyata dengan perlakuan lainnya kecuali dengan perlakuan olah tanah (OT). Perlakuan pupuk kandang ditambah agensia hayati $(\mathrm{PK}+\mathrm{AH})$ merupakan perlakuan yang memiliki tingkat keparahan penyakit embun tepung yang peling rendah.

\section{Keparahan penyakit bercak coklat 1 (Antraknosa)}

Berdasarkan hasil analisis ragam keparahan penyakit bercak coklat 1 . Pada 3 dan 4 MST menunjukkan bahwa perlakuan tidak berbeda nyata atau tidak berpengaruh dan pada minggu 5 dan 6 MST menunjukkan bahwa perlakuan berpengaruh nyata.

Tabel 3. Nilai tengah keparahan penyakit embun tepung pada berbagai perlakuan $(\%)$

\begin{tabular}{lllll}
\hline Perlakuan & \multicolumn{4}{c}{ Umur Tanaman } \\
\cline { 2 - 5 } & $1 \mathrm{MST}$ & \multicolumn{1}{c}{ 3 MST } & \multicolumn{1}{c}{ MST } \\
\hline K & 32,26 & a & 31,51 & 10,67 \\
PK+AH & 18,97 & d & 15,33 & 7,13 \\
AHSI & 20,77 & bcd & 18,15 & 5,99 \\
AHSP & 20,11 & bcd & 18,86 & 10,02 \\
BSP & 25,25 & b & 25,06 & 9,10 \\
PK & 24,65 & bc & 18,03 & 8,63 \\
SL & 22,57 & bcd & 19,38 & 7,58 \\
OT & 30,59 & a & 24,51 & 7,87 \\
\hline F Tabel & $=$ & \multicolumn{5}{r}{6} & 2,76 & 2,76 \\
\hline F Hitung & $=$ & $*$ & 1,07 tn & 0,46 tn
\end{tabular}

Keterangan: Nilai tengah yang diikuti oleh huruf yang sama menunjukkan tidak berbeda nyata (Uji BNT: 0,05$),{ }^{*}=$ berbeda nyata, tn = tidak nyata, $\mathrm{K}=$ kontrol, $\mathrm{PK}+\mathrm{AH}=$ Pupuk kandang ditambah agensia hayati, AHSI $=$ Agensia hayati soil treatment AHSP $=$ Agensia hayati spray, BSP $=$ Bakterisida, $\mathrm{PK}=$ Pupuk kandang, SL $=$ Solarisasi, OT $=$ Olah tanah

Tabel 4. Nilai tengah keparahan penyakit bercak coklat 1 pada berbagai perlakuan $(\%)$

\begin{tabular}{llllll}
\hline Perlakuan & \multicolumn{5}{c}{ Umur Tanaman } \\
\cline { 2 - 6 } & $3 \mathrm{MST}$ & $4 \mathrm{MST}$ & $5 \mathrm{MST}$ & $6 \mathrm{MST}$ \\
\hline K & 3,17 & 4,27 & $5,92 \mathrm{a}$ & 8,19 & $\mathrm{~A}$ \\
PK+AH & 1,96 & 0,98 & $0,70 \mathrm{c}$ & $0,36 \mathrm{D}$ \\
AHSI & 2,38 & 1,15 & $3,04 \mathrm{bc}$ & 1,41 & $\mathrm{Cd}$ \\
AHSP & 2,98 & 2,90 & $2,21 \mathrm{bc}$ & 1,44 & $\mathrm{Cd}$ \\
BSP & 7,22 & 4,22 & $4,74 \mathrm{ab}$ & $3,73 \mathrm{Bc}$ \\
PK & 5,26 & 4,12 & $4,23 \mathrm{ab}$ & $2,74 \mathrm{bcd}$ \\
SL & 3,09 & 3,8 & $4,13 \mathrm{ab}$ & 1,87 & $\mathrm{Cd}$ \\
OT & 4,65 & 3,84 & $3,89 \mathrm{ab}$ & $4,93 \mathrm{~B}$ \\
\hline F Tabel & $=$ & \multicolumn{7}{c}{2,76} & 2,76 & 2,76 \\
\hline F hitung & $=$ & \multicolumn{7}{c}{$1,51 \mathrm{tn}$} & $3,24 *$ & $6,31 *$ \\
\hline Keterangan
\end{tabular}

Keterangan: Nilai tengah yang diikuti oleh huruf yang sama menunjukkan tidak berbeda nyata (Uji BNT: 0,05), *= berbeda nyata, $\mathrm{tn}=$ tidak nyata, $\mathrm{K}=$ kontrol, $\mathrm{PK}+\mathrm{AH}=$ Pupuk kandang ditambah agensia hayati, AHSI = Agensia hayati soil treatment $\mathrm{AHSP}=$ Agensia hayati spray, $\mathrm{BSP}=$ Bakterisida, $\mathrm{PK}=$ Pupuk kandang, $\mathrm{SL}=$ Solarisasi, $\mathrm{OT}=$ Olah tanah
Pada 5 MST, keparahan penyakit bercak coklat 1 pada tanaman pepaya kontrol berbeda dengan keparahan penyakit pada tanaman pepaya yang diberi perlakuan. Perlakuan pupuk kandang ditambah agensia hayati $(\mathrm{PK}+\mathrm{AH})$ menunjukkan keparahan 0,70 $\%$, perlakuan agensia hayati soil treatment (AHSI) menyebabkan keparahan 3,04 \%, agensia hayati spray (AHSP), menunjukkan keparahan 2,21\%, perlakuan bakterisida (BSP) menunjukkan keparahan 4,47 \%, perlakuan pupuk kandang (PK) menunjukkan keterjadian 4,23 \%, perlakuan solarisasi (SL) menunjukkan keparahan 4,13 \%, dan perlakuan olah tanah (OT) menunjukkan keparahan 3,89 \%, Demikan juga keparahan penyakit bercak coklat 1 pada daun pepaya 6 MST menunjukkan bahwa pada tanaman kontrol berbeda dengan tanaman yang diberi perlakuan (Tabel 4).

\section{Keparahan penyakit bercak coklat 2 (Corynespora)}

Berdasarkan hasil analisis ragam keparahan penyakit bercak coklat 2 pada 7 MST menunjukkan bahwa perlakuan yang diterapkan tidak berbeda nyata. Pada pengamatan 8 MST menunjukkan bahwa perlakuan pupuk kandang ditambah agensia hayati, agensia hayati soil treatment, bakterisida, dan solarisasi berbeda nyata dengan kontrol. Sedangkan agensia hayati spray, pupuk kandang dan olah tanah berbeda tetapi tidak nyata dengan kontrol.

Pada pengamatan 9 MST seluruh perlakuan berbeda nyata dengan kontrol kecuali perlakuan olah tanah. Perlakuan agensia hayati soil treatment, agensia hayati spray, bakterisida, dan pupuk kandang tidak berbeda nyata namun perlakuan- perlakuan tersebut memiliki persentase yang lebih kecil dibandingkan dengan kontrol. Sedangkan perlakuan pupuk kandang ditambah agensia hayati merupakan perlakuan yang memiliki persentase yang paling rendah.

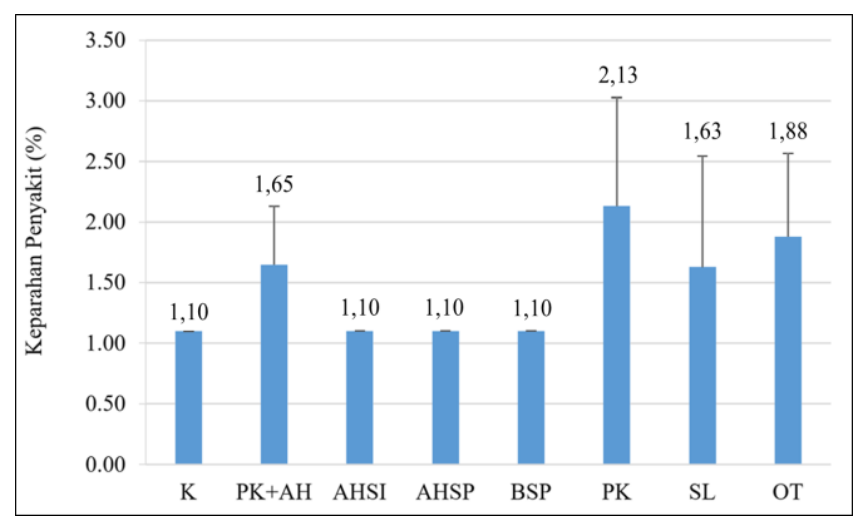

Gambar 9. Keparahan penyakit keriting cladosporium 16 MST. K= kontrol, PK+AH = Pupuk kandang ditambah agensia hayati, AHSI = Agensia hayati soil treatment , AHSP $=$ Agensia hayati spray, BSP $=$ Bakterisida, $\mathrm{PK}=$ Pupuk kandang, SL = Solarisasi, $\mathrm{OT}=$ Olah tanah. 
Pada pengamatan 10 MST sampai dengan 13 MST seluruh perlakuan berbeda nyata dengan kontrol. Perlakuan solarisasi memiliki persentase keparahan penyakit yang paling rendah dari pengamatan 10 MST sampai dengan 16 MST (Tabel 5). Secara keseluruhan pengamatan 7 MST hingga 16 MST perlakuan tidak berpengaruh nyata terhadap keparahan penyakit bercak coklat 2. Tetapi berdasarkan nilai tengah terdapat kecenderungan bahwa perlakuan solarisasi tanah memiliki keparahan penyakit yang lebih rendah dibandingkan dengan perlakuan yang lain (Gambar 9).

\section{Keparahan Penyakit keriting cladosporium}

Berdasarkan hasil analisis ragam keparahan penyakit keriting cladosporium pada 8 MST sampai dengan 16 MST menunjukan bahwa perlakuan yang diterapkan tidak berbeda nyata atau tidak berpengaruh. Pada Gambar 10 yaitu grafik keparahan penyakit keriting cladosporium 16 MST antar perlakuan tidak menunjukan perbedaan keparahan yang signifikan.

\section{Keparahan Penyakit keriting}

Berdasarkan hasil analisis ragam diperoleh bahwa pada 8 MST semua perlakuan tidak berbeda nyata. Pada 9 MST perlakuan berpengaruh nyata atau beda nyata (Tabel 6). Perlakuan pupuk kandang ditambah agensia hayati, agensia hayati soil treatment, agensia hayati spray, pupuk kandang dan olah tanah tidak berbeda nyata dengan kontrol. Perlakuan solarisasi berbeda nyata dengan perlakuannya yang lainnya. Hasil analisi ragam pada 10 MST menunjukan perbedaan yang nyata (Tabel 6), namun seluruh perlakuan tidak berbeda nyata dengan kontrol kecuali perlakuan bakterisida. Perlakuan bakterisida ini diduga membuat daun tanaman menjadi keriting.

\section{Keterjadian Penyakit}

Keterjadian penyakit diukur berdasarkan jenis gejala penyakit yang sistemik. Dari pengamatan di lapangan didapatkan dua jenis penyakit yaitu penyakit busuk akar dan pangkal batang.

Tabel 6. Nilai tengah keparahan penyakit kriting pada berbagai perlakuan $(\%)$

\begin{tabular}{|c|c|c|c|c|}
\hline \multirow[t]{2}{*}{ Perlakuan } & \multicolumn{4}{|c|}{ Umur Tanaman } \\
\hline & $8 \mathrm{MST}$ & $9 \mathrm{MST}$ & $10 \mathrm{MS}$ & \\
\hline$\overline{\mathrm{K}}$ & 14,83 & $15,26 \mathrm{~b}$ & 8,45 & $\mathrm{~b}$ \\
\hline $\mathrm{PK}+\mathrm{AH}$ & 12,14 & $11,22 \mathrm{bc}$ & 6,21 & $\mathrm{~b}$ \\
\hline AHSI & 12,44 & 9,76 bc & 3,13 & $\mathrm{~b}$ \\
\hline AHSP & 10,73 & $13,09 \mathrm{bc}$ & 5,14 & $\mathrm{~b}$ \\
\hline $\mathrm{BSP}$ & 10,72 & $25,66 \mathrm{a}$ & 21,50 & a \\
\hline PK & 13,03 & $8,99 \mathrm{bc}$ & 10,48 & $\mathrm{~b}$ \\
\hline SL & 8,31 & $8,10 \mathrm{c}$ & 2,29 & $\mathrm{~b}$ \\
\hline OT & 9,68 & $12,56 \mathrm{bc}$ & 4,75 & $\mathrm{~b}$ \\
\hline F Tabel $=$ & 2,76 & 2,76 & 2,76 & \\
\hline $\mathrm{F}$ hitung $=$ & $1,08^{\text {tn }}$ & $5,76^{*}$ & $3,87^{*}$ & \\
\hline
\end{tabular}

Keterangan: Nilai tengah yang diikuti oleh huruf yang sama menunjukkan tidak berbeda nyata (Uji BNT: 0,05), *= berbeda nyata, $\mathrm{tn}=$ tidak nyata, $\mathrm{K}=$ kontrol, $\mathrm{PK}+\mathrm{AH}=$ Pupuk kandang ditambah agensia hayati, AHSI $=$ Agensia hayati soil treatment , AHSP $=$ Agensia hayati spray, BSP $=$ Bakterisida, $\mathrm{PK}=$ Pupuk kandang, SL = Solarisasi, OT = Olah tanah

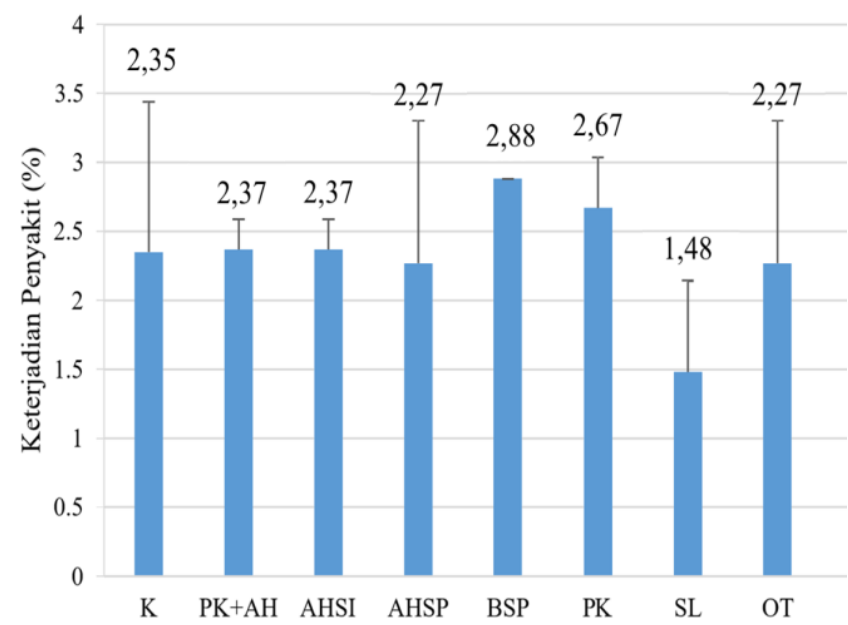

Gambar 10. Keterjadian penyakit busuk akar dan pangkal batang 16 MSI. K= kontrol, $\mathrm{PK}+\mathrm{AH}=$ Pupuk kandang ditambah agensia hayati, $\mathrm{AHSI}=$ Agensia hayati soil treatment, AHSP =Agensia hayati spray, BSP = Bakterisida, $\mathrm{PK}=$ Pupuk kandang, $\mathrm{SL}=$ Solarisasi, $\mathrm{OT}=$ Olah tanah.

Tabel 5. Nilai tengah keparahan penyakit bercak coklat 2 pada berbagai perlakuan (\%)

\begin{tabular}{|c|c|c|c|c|c|c|c|c|c|c|}
\hline \multirow[t]{2}{*}{ Perlakuan } & \multicolumn{10}{|c|}{ Umur Tanaman } \\
\hline & $7 \mathrm{MST}$ & $8 \mathrm{MST}$ & 9 MST & $10 \mathrm{MST}$ & 11 MST & $12 \mathrm{MST}$ & 13 MST & 14 MST & 15 MST & $16 \mathrm{MST}$ \\
\hline$\overline{\mathrm{K}}$ & 14,87 & $14,57 \mathrm{a}$ & $12,60 \mathrm{a}$ & 4,74 a & $4,47 \mathrm{a}$ & $4,76 \mathrm{a}$ & 4,78 a & 4,80 & 5,12 & 5,22 \\
\hline $\mathrm{PK}+\mathrm{AH}$ & 12,11 & $9,88 \mathrm{~b}$ & $3,35 \mathrm{c}$ & $3,54 \mathrm{~b}$ & $3,46 \mathrm{~b}$ & $3,41 \mathrm{~b}$ & $3,74 \mathrm{~b}$ & 4,25 & 4,49 & 4,58 \\
\hline AHSI & 8,58 & $9,46 \mathrm{~b}$ & $4,33 \mathrm{bc}$ & $3,79 \mathrm{~b}$ & $3,67 \mathrm{~b}$ & $3,38 \mathrm{~b}$ & $3,95 \mathrm{~b}$ & 4,25 & 4,29 & 4,42 \\
\hline AHSP & 9,71 & $9,53 \mathrm{ab}$ & $6,90 \mathrm{bc}$ & $3,75 \mathrm{~b}$ & $3,35 \mathrm{~b}$ & $3,11 \mathrm{~b}$ & $3,65 \mathrm{~b}$ & 4,14 & 4,46 & 4,79 \\
\hline BSP & 9,89 & $11,56 \mathrm{~b}$ & 7,10 bc & $3,72 \mathrm{~b}$ & $3,32 \mathrm{~b}$ & $3,31 \mathrm{~b}$ & $3,98 \mathrm{~b}$ & 4,24 & 4,28 & 4,56 \\
\hline PK & 12,20 & $11,28 \mathrm{ab}$ & $7,50 \mathrm{bc}$ & $3,53 \mathrm{~b}$ & $3,67 \mathrm{~b}$ & $3,39 \mathrm{~b}$ & $3,93 \mathrm{~b}$ & 4,20 & 4,24 & 4,50 \\
\hline SL & 6,46 & $9,02 \mathrm{~b}$ & $3,53 \mathrm{c}$ & $3,44 \mathrm{~b}$ & $3,21 \mathrm{~b}$ & $2,42 \mathrm{~b}$ & $3,53 \mathrm{~b}$ & 4,09 & 4,03 & 4,15 \\
\hline $\mathrm{OT}$ & 10,01 & $11,52 \mathrm{ab}$ & $8,39 \mathrm{ab}$ & $3,73 \mathrm{~b}$ & $3,38 \mathrm{~b}$ & $3,48 \mathrm{~b}$ & $3,79 \mathrm{~b}$ & 3,94 & 4,06 & 4,24 \\
\hline F tabel & 2,76 & 2,76 & 2,76 & 2,76 & 2,76 & 2,76 & 2,7 & & 2,76 & 2,76 \\
\hline F hitung & $1,75^{\text {tn }}$ & $3,50 *$ & $4,73^{*}$ & $3,12^{*}$ & $5,63^{*}$ & 2,77 & 1,5 & & $1,92^{\text {tn }}$ & $2,41^{\text {tn }}$ \\
\hline
\end{tabular}

Keterangan: + = bergejala, - = tidak bergejala 


\section{Keterjadian penyakit busuk akar dan pangkal batang}

Berdasarkan hasil analisis ragam keterjadian penyakit busuk akar dan pangkal batang tanaman pepaya pada 2 MST sampai dengan 16 MST menunjukan bahwa perlakuan yang diterapkan tidak berbeda nyata atau tidak berpengaruh. Pada (Gambar 10) terlihat bahwa solarisasi tanah merupakan perlakuan yang memiliki persentase serangan yang paling rendah.

\section{Tinggi Tanaman}

Berdasarkan hasil analisis ragam tinggi tanaman pepaya pada 2 MST dan 4 MST menunjukan bahwa perlakuan yang diterapkan tidak berbeda nyata atau tidak berpengaruh. Namun pada pengamatan 6 hingga 16 MST menunjukkan bahwa perlakuan berpengaruh nyata terhadap tinggi tanaman. Pada 6 MST perlakuan bakterisida dan olah tanah tidak berbeda nyata. Perlakuan tersebut menghasilkan tinggi tanaman yang lebih rendah dibandingkan dengan kontrol. Sedangkan perlakuan pupuk kandang ditambah agensia hayati, solarisasi, dan agensia hayati soil treatment tidak berbeda nyata. Namun perlakuan tersebut memiliki tinggi tanaman yang lebih baik dibandingkan perlakuan kontrol.

Hasil pengamatan pada 8 MST menunjukan bahwa perlakuan pupuk kandang di tambah agensia hayati, dan perlakuan solarisasi berbeda nyata dengan kontrol. Perlakuan solarisasi memiliki tinggi tanaman yang lebih baik dibandingkan dengan perlakuan yang lainnya. Hasil pengamatan pada 10 MST, perlakuan olah tanah tidak berbeda nyata di bandingkan dengan kontrol. Perlakuan tersebut menghasilkan tinggi tanaman yang lebih rendah dibandingkan dengan perlakuan yang lainnya. perlakuan aplikasi pupuk kandang tidak berbeda nyata dengan perlakuan solarisasi. Perlakuan tersebut menghasilkan tinggi tanaman yang lebih tinggi dibandingkan dengan perlakuan kontrol.

Hasil pengamatan pada 12 hingga 16 MST menunjukan bahwa perlakuan solarisasi merupakan perlakuan yang lebih efektif. Perlakuan ini menghasilkan tinggi tanaman yang lebih baik dibandingkan dengan perlakuan yang lainnya. Nilai tinggi tanaman dapat dilihat pada Tabel 7.

\section{Pembahasan}

Hasil penelitian menunjukan bahwa pada setiap tanaman uji muncul lebih dari satu gejala penyakit. Kemunculan penyakit yang berbeda - beda hal tersebut dikarenakan kerentanan dan virulensi patogen tidak berubah dalam jangka waktu tertentu (Supialena, 2017). Gejala-gejala penyakit yang muncul diantaranya, embun tepung, bercak coklat 1 , bercak coklat 2, busuk akar dan pangkal batang, bercak cladosporium dan keriting pada daun pepaya. Menurut semangun (2007), beberapa penyakit yang ditemukan pada pertanaman pepaya yaitu penyakit busuk akar dan pangkal batang, bercak daun Corynespora, Papaya ringspot virus (PRSV), mosaik pepaya, busuk buah antraknosa, busuk buah Rhizopus dan penyakit mati pucuk yang disebabkan oleh Erwinia papaya. Penyakit pada tanaman pepaya yang disebabkan oleh patogen Cladosporium cladosporioides pertama kali di publikasikan oleh Widodo dan Wiyono (2012).

Hasil analisis menunjukan bahwa semua perlakuan yang diterapkan berbeda nyata terhadap keparahan penyakit embun tepung, bercak coklat 2, dan bercak coklat 1 . Dengan perlakuan yang paling efektif yaitu pupuk kandang ditambah agensia hayati $(\mathrm{PK}+\mathrm{AH})$. Menurut Suryawan dkk. (2017) aplikasi pupuk kandang sapi di tanaman strowberi di rumah kaca memiliki persentase serangan jamur Verticillium sp. sebesar 36,66 \%. Sedangkan kombinasi antara pupuk kandang dan agensia hayati memiliki persentase serangan sebesar 6,66 \%. Selain itu, menurut Asniah dkk, (2012), aplikasi pupuk kandang sapi dapat menekan keparah penyakit sampai 34,67 \%. Hal tersebut sejalan dengan penelitian ini yang dimana perlakuan kombinasi antara pupuk kandang dan agensia hayati memiliki persentase keparahan yang paling rendah.

Tabel 7. Nilai tengah tinggi tanaman pada beberapa perlakuan $(\mathrm{cm})$

\begin{tabular}{|c|c|c|c|c|c|c|c|c|c|c|c|c|c|c|c|}
\hline \multirow{3}{*}{$\begin{array}{l}\text { Perlakuan } \\
\mathrm{K}\end{array}$} & \multicolumn{15}{|c|}{ Umur Tanaman } \\
\hline & \multicolumn{2}{|c|}{$2 \mathrm{MST}$} & \multicolumn{2}{|c|}{$4 \mathrm{MST}$} & \multicolumn{2}{|c|}{6 MST } & \multicolumn{2}{|l|}{$8 \mathrm{MST}$} & \multicolumn{2}{|c|}{$10 \mathrm{MST}$} & \multicolumn{2}{|c|}{$12 \mathrm{MST}$} & \multicolumn{2}{|c|}{14 MST } & 16 MST \\
\hline & 12.55 & $\mathrm{a}$ & 17.28 & $\mathrm{a}$ & 21.94 & $\mathrm{bc}$ & 27.89 & cde & 32.24 & $\mathrm{~cd}$ & 39.66 & $\mathrm{bc}$ & 45.26 & $\mathrm{c}$ & $47.13 \mathrm{c}$ \\
\hline $\mathrm{PK}+\mathrm{AH}$ & 14.80 & $\mathrm{a}$ & 23.22 & $\mathrm{a}$ & 32.51 & $\mathrm{a}$ & 41.06 & $a b$ & 46.20 & $\mathrm{a}$ & 57.49 & $\mathrm{ab}$ & 69.98 & $a b$ & $74.03 \mathrm{ab}$ \\
\hline AHSI & 15.58 & $\mathrm{a}$ & 20.90 & $\mathrm{a}$ & 29.07 & $\mathrm{abc}$ & 37.84 & abc & 41.01 & abc & 49.87 & abc & 56.94 & $\mathrm{abc}$ & 61.14 abc \\
\hline AHSP & 13.27 & $\mathrm{a}$ & 18.05 & a & 21.98 & bc & 29.34 & bcde & 33.08 & bcd & 40.43 & $\mathrm{bc}$ & 50.44 & $\mathrm{bc}$ & $59.56 \mathrm{bc}$ \\
\hline BSP & 13.76 & $\mathrm{a}$ & 17.78 & a & 20.13 & $\mathrm{c}$ & 25.67 & de & 27.22 & $\mathrm{~d}$ & 32.22 & $\mathrm{c}$ & 41.00 & $\mathrm{c}$ & $39.44 \mathrm{c}$ \\
\hline PK & 14.81 & $\mathrm{a}$ & 23.00 & $\mathrm{a}$ & 30.86 & $a b$ & 37.56 & abcd & 45.75 & $a b$ & 61.83 & $\mathrm{a}$ & 69.08 & $a b$ & $81.17 \mathrm{ab}$ \\
\hline $\mathrm{SL}$ & 15.26 & $\mathrm{a}$ & 22.60 & a & 31.66 & $\mathrm{a}$ & 43.12 & $\mathrm{a}$ & 45.65 & $a b$ & 61.90 & $\mathrm{a}$ & 76.55 & $\mathrm{a}$ & $82.42 \mathrm{a}$ \\
\hline $\mathrm{OT}$ & 13.49 & $\mathrm{a}$ & 18.65 & $\mathrm{a}$ & 21.73 & $\mathrm{c}$ & 25.55 & $\mathrm{e}$ & 31.13 & $\mathrm{~cd}$ & 41.44 & $a b c$ & 51.33 & $\mathrm{bc}$ & $63.13 \mathrm{abc}$ \\
\hline F Tabel $=$ & 2.76 & 2.76 & & 2.76 & & 2.76 & & & 2.76 & & 2.76 & 2.76 & & 2.76 & \\
\hline F hitung= & $0.38^{\text {tn }}$ & $1.40^{\mathrm{tn}}$ & & $3.06^{*}$ & & $3.29 *$ & & & $3.22^{*}$ & & $2.83 *$ & $2.79 *$ & & $3.23 *$ & \\
\hline
\end{tabular}

Keterangan: Nilai tengah yang diikuti oleh huruf yangsama menunjukan tidak berbeda nyata (Uji BNT: 0,05), *= berbeda nyata, tn $=$ tidak nyata, $\mathrm{K}=$ kontrol, $\mathrm{PK}+\mathrm{AH}=$ Pupuk kandang ditambah agensia hayati, AHSI = Agensia hayati soil treatment, AHSP =Agensia hayati spray, BSP = Bakterisida spray, PK = Pupuk kandang, SL = Solarisasi, OT = Olah tanah. 
Peran pupuk kandang sapi juga berpengaruh menekan persentase penyakit karena unsur $\mathrm{N}$ dan $\mathrm{K}$ yang cukup tinggi. Kandungan hara pupuk kandang sapi unsur N $10 \mathrm{~kg} / \mathrm{ton}, \mathrm{P} 2 \mathrm{~kg} / \mathrm{ton}$ dan $\mathrm{K} 8 \mathrm{~kg} / \mathrm{ton}$ (Swahyono, 2014). Nutrisi yang dibutuhkan oleh tanaman tidak terlepas dari tiga unsur hara, yaitu nitrogen $(\mathrm{N})$, fosfor $(\mathrm{P})$, dan kalium (K). Unsur nitrogen merupakan komponen utama dari protein yang cepat kelihatan pengaruhnya pada tanaman dan bermanfaat memacu pertumbuhan secara umum, terutama pada fase vegetative. Unsur kalium $(\mathrm{K})$ berperan sebagai activator berbagai enzim dan membantu membentuk protein, karbohidrat dan gula serta memperkuat jaringan tanaman dan meningkatkan daya tahan terhadap penyakit. Sehingga pertumbuhan patogen sedikit terhambat oleh kondisi tersebut.

Demikian juga yang terjadi pada agensia hayati (Aspergillus sp. dan Talaromyces sp.) yang digunakan memiliki kemampuan antagonis terhadap patogen tanaman. Menurut Supriyanto dkk, (2011), kedua jamur ini dapat mengendalikan Erwinia chrysanthemi. Selain itu, jamur Talaromyces sp. dapat menghambat pertumbuhan Fusarium oxysporum f.sp cubense (Suciatmih dkk., 2014), Verticillium alboatrum, V. dahlia, Rhizoctonia solani dan Sclerotinia sclerotium (Gohel dkk, 2006).

Menurut Purkan dkk. (2016), jamur Aspergillus sp. menghasilkan enzim ekstraseluler seperti kitinase dan selulase. Enzim kitinase digunakan untuk mendegradasi dinding sel patogen yang terdiri dari kitin seperti dinding sel jamur, nematode, dan serangga. Enzim selulase digunakan untuk mengkolonisasi daerah interseluler jaringan korteks akar, sehingga terjadi penghambatan invasi patogen. Selain sebagai antagonis jamur ini dapat berperan sebagai "Plant Growth Promoting Fungi" (PGPF) hal terebut dikarenakan jamur Aspergillus sp. dapat menghasilkan hormon pertumbuhan diantaranya IAA dan GA (Pandya dkk., 2018).

Pengamatan keterjadian penyakit busuk akar dan pangkal batang pepaya tidak berpengaruh nyata. Namun hasil penelitian (Gambar 10) menunjukkan bahwa perlakuan solarisasi tanah merupakan perlakuan yang berpotensi untuk mengendalikan penyakit busuk akar dan pangkal batang pepaya. Menurut Semangun (2007), penyakit busuk akar dan pangkal batang disebabkan oleh jamur Phytophthora sp. Jamur ini merupakan jamur tular tanah.

Solarisasi tanah merupakan salah satu teknik pengendalian penyakit untuk patogen-patogen tular tanah. Solarisasi tanah dapat memodifikasi lingkungan dengan meningkatkan suhu tanah yang mengakibatkan perubahan fisik, kimia dan biologi tanah. Menurut Saylendra (2009) solarisasi tanah selama 4 minggu memiliki suhu harian rata-rata $37,50^{\circ} \mathrm{C}$. Kisaran suhu tersebut sudah cukup untuk menekan patogen tular tanah. Menurut Sastrahidayat (2011) Phytophthora sp., dapat hidup pada kisaran suhu $12-24^{\circ} \mathrm{C}$ dan termasuk dalam kategori jamur mesofilik. Oleh karena itu, perlakuan solarisasi tanah dapat menekan keterjadian penyakit busuk akar dan pangkal batang pepaya.

Pengamatan juga dilakukan terhadap variabel pertumbuhan. Dari hasil pengamatan menunjukan bahwa perlakuan pupuk kandang ditambah agensia hayati, solarisasi tanah dan aplikasi pupuk kandang berpengaruh nyata untuk tinggi tanaman dibandingkan dengan kontrol. Hal ini dikarenakan pupuk kandang berperan dalam kesuburan tanah dengan menyediakan zat dan nutrient, seperti nitrogen yang ditangkap mikroba dalam tanah. Pupuk kandang merupakan pupuk lengkap karena umumnya mengandung semua unsur hara yang diperlukan oleh tanaman, baik unsur hara makro $(\mathrm{N}, \mathrm{P}, \mathrm{K})$ maupun unsur-unsur lain $(\mathrm{Ca}, \mathrm{Mg}, \mathrm{Cu}$, serta sejumlah kecil $\mathrm{Mn}$ dan $\mathrm{BaO}$ yang semuanya merupakan unsur-unsur atau zat makanan yang dibutuhkan oleh tumbuhan bagi pertumbuhan dan perkembangannya (Suridikarta dkk., 2006). Selain itu, agensaia hayati (Aspergillus sp.) yang di kombinasikan menghasilkan fitohormon seperti IAA dan GA (Purkan dkk., 2016). Fitohormon atau zat pengatur tumbuh merupakan senyawa yang dalam jumlah sedikit dapat berpengaruh besar terhadap pertumbuhan tanaman.

Menurut Brugman dkk., (2017), solarisasi tanah selama 4 minggu dapat meningkatkan produksi tanaman kentang sebesar 14,28 \%. Hal ini juga terlihat dalam penelitian ini, dimana perlakuan solarisasi memiliki tinggi tanaman yang lebih baik dibandingkan dengan perlakuan yang lainnya. Menurut Paiman dkk., (2013), solarisasi tanah mampu menekan pertumbuhan gulma. Energi panas yang terjebak dibawah mulsa plastik akan mempengaruhikondisi fisik, biologi dan kimia tanah yaitu menungkatkan suhu tanah, menekan pertumbuhan gulma dan meningkatkan aktivitas mikroorganisme (Fahrurrozi, 2009). Pertumbuhan gulma yang terkendali mengakibatkan pertumbuhan tidak terganggu. Oleh karena itu, pada penelitian ini perlakuan solarisasi merupakan perlakuan yang memiliki tinggi tanaman yang paling baik diantara perlakuan yang lainnya. Hal ini salah satunya disebabkan karena pertumbuhan gulma terhambat. Sehingga pertumbuhan tanaman tidak terganggu.

\section{Pernyataan tidak ada konfik kepentingan}

Semua penulis artikel ini menyatakaan bahwa tidak ada konflik kepentingan terkait penelitian dan hasil penelitian ini.

\section{DAFTAR PUSTAKA}

Asniah, A. Khaeruni, \& H. Anwar. 2012. Penggunaan pupuk kandang terhadap efektifitas Trichoderma viride untuk mengendalikan penyakit layu fusarium pada tanaman tomat. Jurnal Agroteknos. 2(1):28 - 35. 
Badan Pusat Statistik (BPS). 2018. Produksi Buah Pepaya di Provinsi Lampung. https://www.bps.go.id/site/resultTab. Diakses pada tanggal 1 Februari 2019

Brugman, E., E.D. Purbajanti, \& E. Fuskhah. 2017. Pengendalian penyakit hawar (lateblight) pada kentang (Solanum tuberosum L) melalui penerapan solarisasi tanah dan aplikasi agensia hayati Trichoderma harzianum. Jurnal Agro Complex. 1(2): 31-38.

Cunningham, B. \& S. Nelson. 2012. Powdery Mildew of Papaya In Hawai'i. https://www.ctahr.hawaii.edu/oc/freepubs/pdf/PD90.pdf. Diakses pada tanggal 19 Juni 2019

Fahrurrozi. 2009. Fakta Ilmiah Dibalik Penggunaan Mulsa Plastik Hitam Perak dalam Produksi Tanaman Sayuran. http://unib.ac.id/blog/fahrurrozi/2009/03/16/mulsa-plasikhitam/perak/ . Diakses pada tanggal 28 Juni 2019

Gaulin E., A., JAuneau, F., Villalba, M., Rickauer, M. T. E., Tugaye \& A. Bottin. 2002. The CBEL glycoprotein of Phytophthora parasitica var. nicotianae is involved in cell wall deposition and adhesion to cellulosic substrates. Journal of Cell Science. 115(23): 4565-4575

Ginting, C. 2013. Ilmu Penyakit Tumbuhan Konsep dan Aplikasi. Lembaga Penelitian, Universitas Lampung. Bandar Lampung.

Gohel, V., Aa. Singh, M. Vimal, P. Ashwini, \& H. S. Chhatpar. 2006. Bioprospecting and antifungal potential of chitinolytic microorganisms. African Jurnal of Biotechnology. 5(2): 54-72.

Hidayat, S. H., S, Nurulita, \& S. Wiyono. 2012. Infeksi papaya ringspot virus pada tanaman papaya di provinsi Nanggroe Aceh Darussalam. Jurnal Fitopatologi Indonesia. 6(8): 184187.

Kumar S., \& R. Singh. 2016. Corynespora celastri sp. nov. on Celastraceae from India. Studies in Fungi. 1(1): 125-129.

Ministry of Agriculture of India. 2014. AESA Based IPM Package Papaya. National Institute of Plant Health Managemant. India.

Muktiani. 2011. Bertanam Varietas Unggul Pepaya California. Pustaka Baru. Yogyakarta.

Paiman, P. Yudono, B. H. Sunarminto \& D. Indradewa. 2013. Kajian solarisasi tanah dan jarak tanam terhadap pertumbuhan gulma dan hasil cabai. AGRO UPY. 5(1) : 1-12.

Pandya, N.D., P. V. Desar, \& R. Z. Sayyed. 2018. Plant growth promoting potensial Aspergillus sp. NPF7, isolated from wheat rhizosphere in south Gujarat, India. Evironmental Sustainabelity. 1(3): 245-252.

Purkan, P., A. Baktir \& A. R. Sayyidah. 2016. Produksi enzim kitinase dari Aspergillus niger menggunakan limbah cangkang rajungan sebagai induser. Journal Kimia Riset. 1(1): $34-41$.

Saylendra, A. 2009. Pengendalian penyakit layu fusarium pisang (Fusarium oxysporum f.sp. cubense) dengan solarisasi tanah dan bakteri antagonis. Jurnal Agroekotek. 1(1): 1-6.
Semangun, H. 2007. Penyakit-penyakit Tanaman Hortikultura di Indonesia. Gadjah Mada University Press. Yogyakarta.

Silva D. D. P., J. R. G. Araujo, A. A. C. Rodrigues, E. K. C. Silva, $\&$ N. B. Diniz. 2018. Reaction of papaya genotypes to target spot and activity of plant extracts and Bacillus spp. on Corynespora cassiicola. Revista Brasileira de Fruticultura. 40(1): $1-8$

Singh, C. K., I., Sudhir, R., Chand, V., Singh \& M., Sharma. 2017. Variability in Phytophthora drechsleri f.sp. cajani and effect temperature. Journal of Pure and Applied Microbiology. 11 (2): $1053-1059$

Suciatmih, S. Antonius, I. Hidayat, T.R. \& Sulistiyani. 2014. Isolasi, identifikasi dan evaluasi antagonism terhadap Fusarium oxysporum f.sp. cubense (Foc) secara in vitro dari jamur endofit tanaman pisang. Berita Biologi. 13(1): 71-83.

Supriyanto, A. Priyatmojo, \& T. Arwiyanto. 2011. Uji penggabungan PGPF dan Pseudomonas putida strainPF-20 dalam pengendalian hayati busuk lunak lidah buaya di tanah gambut. Jurnal Hama dan Penyakit Tumbuhan Tropika. 11(1): $11-21$

Suridikarta, D.A. 2006. Pupuk Organik dan Pupuk Hayati. Badan Penelitian dan Pengembangan Pertanian. Bandung.

Suryawan L., G. A. S. Wirya, \& I. P., Sudiarta. 2017. Penggunaan Trichoderma sp. yang ditambahkan pada berbagai kompos untuk pengendalian penyakit layu tanaman stroberi (Fragaria sp.). E-Jurnal Agroekoteknologi Tropika. 6 (4): 481490

Swahyono, U. 2014. Cara Cepat Buat Kompos dari Limbah. Penebar Swadaya. Jakarta.

Torres, D.E., R.I.R. Martinez, E.Z. Mejia, P.G. Fefer, G.J.M Guzman, \& C.P Martinez. 2017. Cladosporium cladosporioides and Cladosporium pseudocladosporioides as potential new fungal antagonists of Puccinia horiana Hen., the causal agent of chrysanthemum white rust. Jurnal PlosOne. 12(1):1-16.

Watanabe, T. 2002. Pictorial atlas of Soil and Seed Fungi Morphologies of Cultured Fungi and Key to Species. CRC Press. Amerika.

Widodo \& S. Wiyono. 2012. Penyakit keriting daun pepaya yang disebabkan oleh Cladosporium cladosporides. Jurnal Fitopatologi Indonesia. 8(1): 28-29.

Wike S., L., Cai, N., Pairin, H. C. Eric, Mckenzle, Y. Y. Su, E. Chukeatirote, H.N. Thi, A. H. Bahkali, M. A. Moslem, K. Abdelsalam, \& K. D. Hyde. 2011. Colletotrichum spesies from jasmine (Jasminum sambac). Fungal Diversity. 46(1): 171-182

Wiyono, S., \& S. Manuwoto. 2008. Penyakit Antraknosa pada Pepaya dan Potensi Pengendaliannya. Pusat Kajian Buah Tropika. Bogor. 